\title{
Improving Access to Productive Resources and Agricultural Services through Gender Empowerment: A Case Study of Three Rural Communities in Ambo District, Ethiopia
}

\author{
G. S. Ogato ${ }^{1}$ E. K. Boon ${ }^{2}$ and J. Subramani ${ }^{3}$ \\ ${ }^{1}$ Department of Cooperatives, Ambo University College, Ethiopia \\ E-mail: gemechushale2005@yahoo.com \\ ${ }^{2}$ Human Ecology Department, Vrije Universiteit Brussel, Belgium \\ E-mail: eboon@vub.ac.be \\ ${ }^{3}$ Department of Cooperatives, Ambo University College, Ethiopia \\ E-mail: drjsmindia2008@gmail.com
}

\begin{abstract}
KEYWORDS Gender. Agricultural Development Policy. Agricultural Services. Credit. Programme. Irrigation Productive Resources. Rural Institutions

ABSTRACT This article is the second of two papers produced through a research on gender in agriculture that was conducted in Ambo district, Ethiopia, between July and September 2007. The first article was on "Gender Roles in Crop Production and Management Practices: A Case Study of Three Rural Communities in Ambo District, Ethiopia". Employing the concept of gender empowerment, this second paper identifies and analyzes the factors constraining the productivity of female farmers in the district. Primary data were collected through questionnaires, interviews, observations, focus group discussions, participatory rural appraisal, gender analysis and case studies (life history approach). The statistical package for social science (SPSS) was used to analyze data from the field. Excel spreadsheet was used to summarize and analyze the data collected through focus group discussions, participatory rural appraisal and interviews. The results of the study indicate that gender-neutral crop production and management interventions do not have the same impact on rural male and female farmers. The latter have limited access to key productive resources such as land, irrigation water, extension services, credit and rural institutions. The conditions of both rural male and female farmers in Ethiopia can be significantly enhanced if agricultural development policies are improved and the existing gender-neutral extension services made gender responsive, and access by female farmers to productive resources improved through the formulation and implementation of effective gender empowerment strategies.
\end{abstract}

\section{INTRODUCTION}

Gender related constraints reflect gender inequalities in access to resources and development opportunities. Although class, poverty, ethnicity and physical location may influence these inequalities, the gender factor tends to make them more severe (Kabeer 2003). Access to productive assets is a major issue in the gender empowerment discourse. Despite the significant roles women play in agriculture and food security in many developing countries, they continue to have a poorer command over a range of productive resources, including education, land, information, and financial resources (World Bank 2001; Odame et al. 2002; Welch et al. 2000).

Gender could be defined as "the rules, norms, customs and practices by which biological differences between males and females are translated into socially constructed differences between men and women and boys and girls" (Kabeer 2003; IIRR-Ethiopia 2000). Empowerment is a term used generally to describe the process by which powerless people become conscious of their own situation and organize collectively to gain greater access to public services or to the benefits of economic growth (CIDA 1997). Gender empowerment in Ethiopia requires economic, legislative and policy measures to improve the conditions of both male and female population. Economic empowerment of women significantly impacts livelihood at the household, community and national levels (Africa Partnership Forum and New Partnership for Africa's Development 2007). Empowering women is a key to achieving food security (Olumakaiye and Ajayi 2006). Improving access by small-scale farmers to productive resources is one of the best mechanisms for ensuring sustainable human development (Bhatta 2001). Legislative reforms can be a powerful strategy for empowering women and girls and safeguarding their rights (United Nations Children's Fund 2006; Baden and Reeves 2000). Scholars of gender studies advise that an effective participation of women in formal politics requires effective support for broad programmes of 
democratization and good governance. A strong focus on developing the civil society is also an important strategy for promoting gender empowerment (Baden and Oxaal 1997; United Nations Children's Fund 2006).

Following the Beijing conference of 1995, Ethiopia identified poverty and economic empowerment of women and girls; education and training of women and girls; promotion of reproductive rights, health and control of HIV/ AIDS; promoting human rights, elimination of violence against women and girls; empowering women in decision-making; and forging positive links between women and the environment; and introducing institutional mechanisms for the advancement of women as priority areas that need to be tackled in order to ensure genderequitable development (MOWA 2006). The gender policy primarily aims to institutionalize the political, economic and social rights of women by creating appropriate structures in government offices and other institutions to make public policies and interventions more gender-sensitive and development oriented (UN 2003; Cherinet and Mulugeta 2003; FAO 1997).

Empowering rural women through improved access to key productive resources and agricultural services is the right choice for developing countries like Ethiopia where rural women's contribution to agricultural production and food security is quite immense. Facilitating access to productive resources - ranging from land and water to infrastructure - by the poor is not a one-time event, but an institutional process that requires permanent adaptation to changing circumstances of power, economics, and culture (IFAD 2007; Peter 2006; Rahman 2000). According to Elson (1998), macro-economic policy can worsen or improve the living standards of different groups of women and contribute to narrowing or widening gender gaps in incomes, health, education, nutrition, etc. An effective macro-economic policy is required for improving the livelihood of the marginalized sections of society, especially rural men and women. Such a policy could create a virtuous circle in which the policy itself contributes to the reduction of gender inequality, and thereby lessen gender constraints and successful macro-economic outcomes (Elson 1998).

Over the years, the government of Ethiopia has been making efforts to empower women in decision-making processes in order to facilitate the attainment of the country's sustainable development goals. The establishment of the Women's Affairs Office in the country and the formulation of a national policy on women, which entitles and ensures women's right to property, employment and pension illustrate the commitment of the government to gender empowerment (United Nations 2002). Nevertheless, gender empowerment in the country is facing a number major constraints, including the low level of consciousness by the population about the roles played by women in the development of the country; the deep-rooted cultural beliefs and traditional practices that prevent women from fully participating in the development process of the country; lack of appropriate technology to reduce the workload of women at the household level; and the shortage of qualified female development agents to help motivate and empower rural women (United Nations 2002). Gender empowerment is an important and appropriate instrument for enhancing gender roles in sustainable rural development.

\section{BACKGROUND OF THE PAPER}

Ethiopia is the tenth largest country in Africa, covering an area of 1.1 million $\mathrm{km}^{2}$ with considerable geographical diversity consisting of deserts, lush plateaus, tropical lowlands, high altitude mountains and plains below sea level. The climatic conditions also vary with the topography; temperatures range between $47^{\circ} \mathrm{C}$ in the Afar depression and $10^{\circ} \mathrm{C}$ in the highlands (Cherinet and Mulugeta 2003; Deressa 2007). Agriculture is the main sector of the economy of Ethiopia. The sector is characterized by subsistent, small-scale farming system. About 16.4 million hectares $(14 \%)$ of the total land area are suitable for producing annual and perennial crops. About eight million hectares $(7 \%)$ of the arable land area is used for rain-fed crops (Deressa 2007). Small-scale farmers are the largest group of poor people in Ethiopia. Their average land holdings are less than 1 ha. Rainfed crop production is the basis of all small-scale subsistence farming in most parts of the country and accounts for more than $95 \%$ of the land area cultivated annually. In general, farming is mixed - both animal and crop production are practised (Deressa 2007).

A farm is considered as a system and its elements include people, crops, livestock, vegetation, wildlife and socio-economic and ecological 
factors that interact amongst themselves and shape the farm system. Mixed agriculture in which livestock are used as a source of draft, transportation, and food in the district. Ploughing, crop rotation, terracing, irrigation, and soil fertilization have been practised for years as part of the traditional farming system (Hunduma 2006). A wide variety of crops constitute the agricultural system of the three surveyed communities. Cereals, pulses, and oil crops are the most important crops of the agricultural system. Cereal crops occupy the largest area and Teff is the most important food crop. This crop is however very delicate and fragile and requires a lot of labour and care (Hunduma 2006). Adverse environmental conditions, slow growth of the sector and rapid population growth are the main factors constraining the development of the agricultural sector (Deressa and Kelemework 2005; Cherinet and Mulugeta 2003). The vulnerable nature of agriculture in Ethiopia is due to the declining size of farms; subsistence farming; land degradation due to inappropriate human activities such as cultivation of steep slopes and over-grazing; tenure insecurity; weak agricultural research and extension services; lack of marketing of agricultural products; poor transport network; low use of fertilizers, improved seeds and pesticides; the use of inefficient traditional farm imple-ments; and inappropriate government polices (Deressa 2007).

\section{CONCEPTUAL FRAMEWORK OF THE PAPER}

An effective gender policy is very important to institutionalize gender equality and empowerment in agriculture and rural development strategies of Ethiopia. Improving the access of rural female farmers to productive resources such as land, water and finance can play a significant role in enhancing female farmers' productivity, food security and sustainable development. In addition, access by female farmers' to agricultural services such as credit, extension and rural institutions enables them to manage their environmental and socio-economic challenges in agriculture on a sustainable basis. In other words, rural female farmers in Ambo district in Ethiopia and other African countries can overcome rural poverty through the implementation of effective gender equality and empowerment strategies. The model presented in Figure 1 defines the relationships amongst effective gender policy, gender

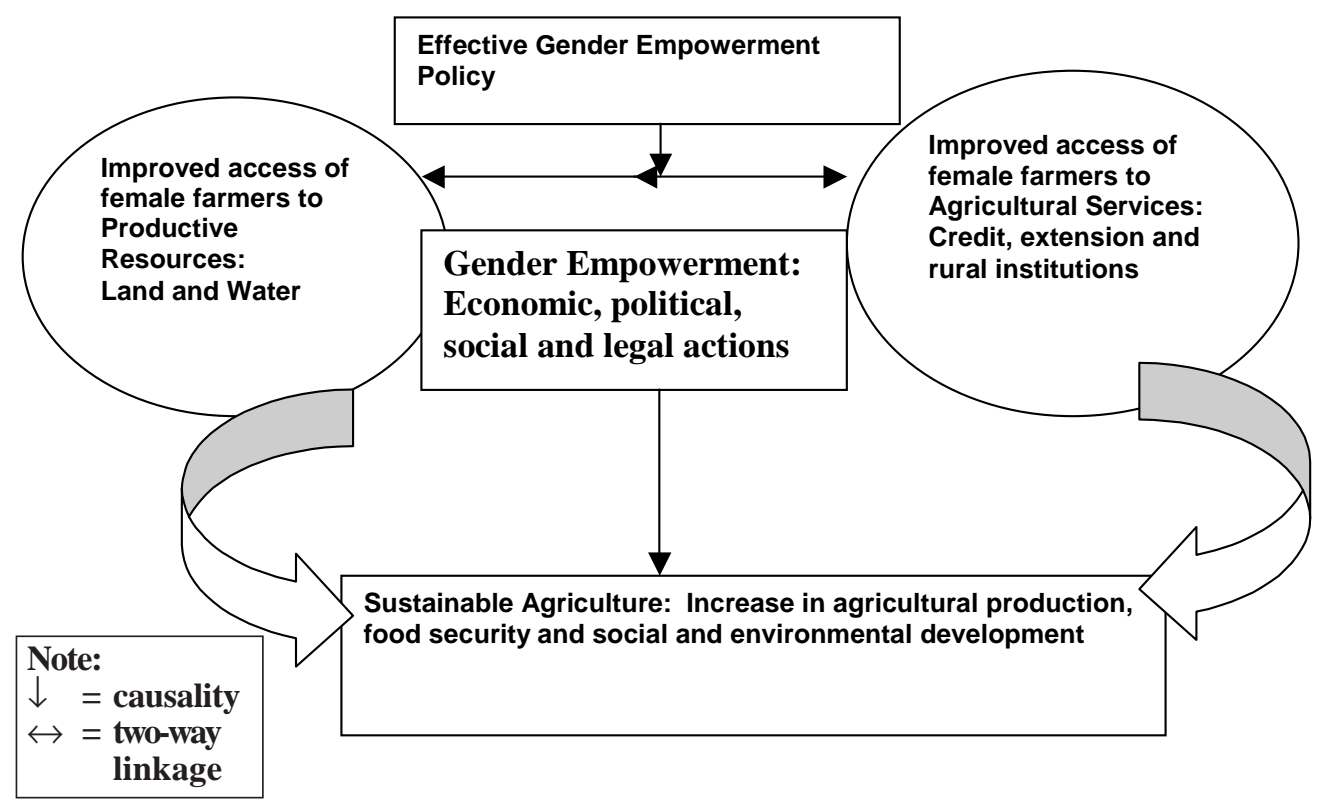

Fig. 1. Model depicting the relationships between gender empowerment policy, gender empowerment actions and sustainable agricultural practices

[Source: Authors' own model 2008]. 
empowerment actions and sustainable agricultural practices.

\subsection{Ethiopia's Gender Empowerment Policy}

Effective gender empowerment policy is a very important component of Ethiopia's sustainable rural agriculture development model. The policy guides all strategies for empowering female farmers at the grass root level. The principal components of the gender empowerment model are briefly described below:

Economic Empowerment: Ethiopian rural women face enormous challenges including lack of education, access to resources such as land, time, capital, and financial services. Economic empowerment is one of the empowerment components that can effectively deal with the complex challenges of rural women (Ruzvidzo 2007; APF and NEPAD 2007; Baden and Oxaal 1997; UNICEF 2006).

Legal Empowerment: Legislative reform can be a powerful strategy for empowering women and girls and safeguarding their rights (UNICEF 2006; Ruzvidzo 2007; Baden and Reeves 2000).

Political Empowerment: Women in politics advocate more often and more strongly for the rights of women, children and families (UNICEF 2006).

Social Empowerment: It is important to organize female farmers into different groups to deal with emerging socio-economic and environmental challenges.

Productive Resources: These resources are used to produce agricultural outputs. Land and irrigation water are the two key productive resources for which access by rural women must be improved to guarantee gender empowerment.

Agricultural Services: These services are important for supporting production and management of agricultural products. Credit and agricultural extension services and rural institutions are important agricultural services for which access of rural women must be improved through gender empowerment.

\section{METHODS AND MATERIALS}

\subsection{Study Location and Characteristics}

Ambo District has a mean annual temperature ranging between $23-25^{\circ} \mathrm{C}$ and a mean annual rainfall of 1300-1700mm (WSZBFED 2007). The lowland, midland and highland cover $17 \%, 60 \%$ and $23 \%$ of the district respectively. The altitudinal range of the agro-climatic zones in the district fall between 500 and 3,200 metres above sea level and represent lowest point of low land and highest point of highland agro-climatic zone respectively.

This study was carried out in three rural communities-Awaro Kora, Senkele Farisi and Gosu Kora- in Ambo district. The district is located in West Shewa zone of Oromia Regional State, Ethiopia (Fig. 2). It is located between $8^{0} 47^{\prime} \mathrm{N}-9^{0}$ $21^{\prime}{ }^{N}$ and $37^{\circ} 32^{\prime} \mathrm{E}-38^{\circ} 3^{\prime} \mathrm{E}$ (Ambo District Finance and Economic Development Office 2007). The capital of West Shewa zone is Ambo town, which is located $125 \mathrm{~km}$ away from Addis Ababa, the capital of Ethiopia.

\subsection{Data Collection and Analysis}

Both secondary and primary data were collected from the three selected communities. An in-depth literature search was conducted to gather information on the scientific, historical and socio-economic aspects of gender roles in agriculture. This information guided the design of appropriate field data collection instruments. The primary data were collected through questionnaires, interviews, observations, focus group discussions, participatory rural appraisal as well as gender and life history analysis. Purposive sampling was used to select three highly productive rural communities while stratified random sampling was employed to select male-headed and female-headed farming households from each community. Farmers from both male and female headed households were picked through simple random sampling. An equal number of females (125) and males (125) farmers were interviewed from the three communities.

Choosing indicators of empowerment depends on the way in which the concept is defined. Gender empowerment in agriculture, which aims at developing and strengthening human and institutional capacity, relies more on process indicators because they involve change over many years (CIDA 1997). The following qualitative indicator questions were used to assess gender empowerment in three communities in Ambo district in Ethiopia:

Do rural male and female farmers have access to credit and agricultural extension services and rural institutions? 


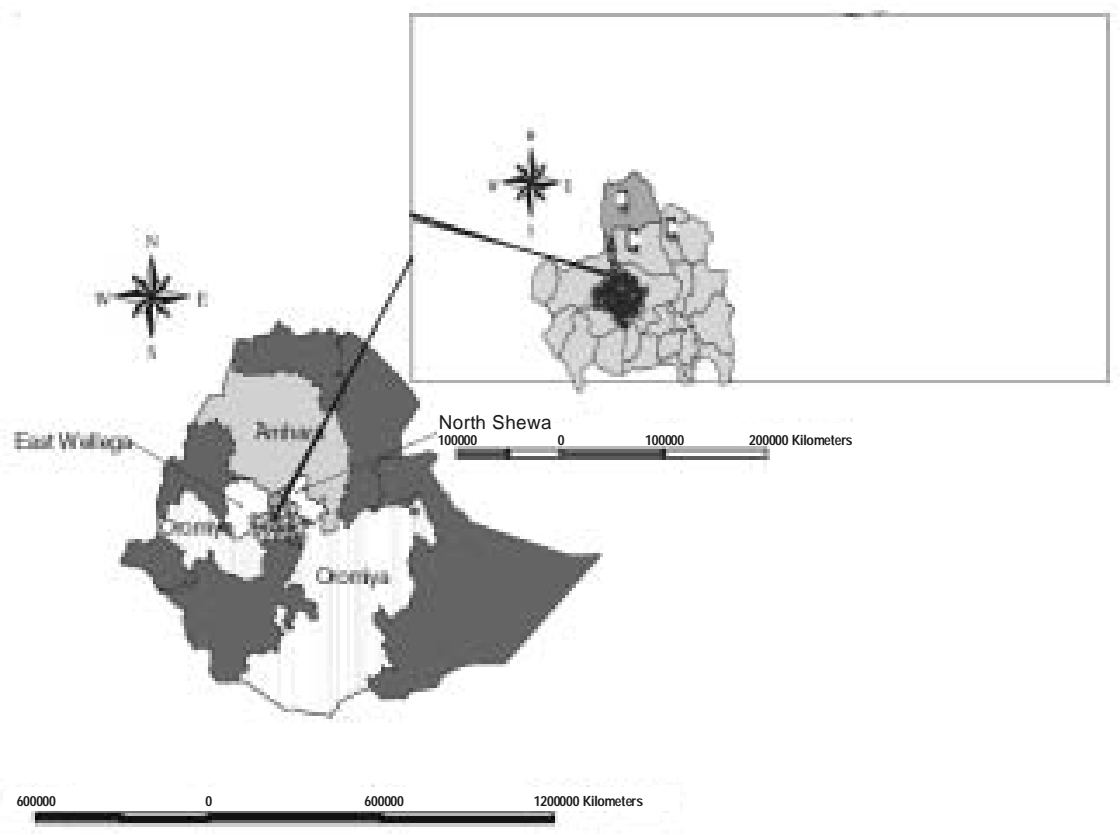

Fig. 2. Map of Ethiopia and West Shewa Zone Showing Ambo District [Source: Adapted from Hunduma 2006].

- Do rural male and female farmers have access to key productive resources like land and irrigation water?

- Do women and men perceive that women are becoming more empowered? Why?

- Do women perceive that they now have greater self-respect? Why? How does this relate to men's perceptions?

- Do women/men perceive that they now have greater economic autonomy? Why?

- Are changes taking place in the way in which decisions are made in the household? And what is the perceived impact of this?

- Do women make decisions independently of men in their household? What sort of decisions is made independently?

- How have changes in national/local legislation empowered or disempowered women as opposed to men (e.g. concerning control over resources such as land)?

- What is the role of local institutions (including women's institutions) in empowering/ disempowering women/men?

- Do women and men have equal access to new technologies (new seed varieties etc) introduced by extension services and other agencies?

- What channels of access to information and technology exist for women/men and poor/ wealthy?

- Do local cooperatives, and other formal and informal networks or groups exist? Who are the members?

- Why have members formed or joined such groups (ie. what were their expectations of the group(s)?

- Do women and men rely on different kinds of formal and informal groups, networks, and relationships for access to information, technology, and productive resources?

- Are there mechanisms in place at the regional and national levels of government to issues of gender equity?

- Are there cultural norms/legal frameworks in place which limit women's /men's access to resources and opportunities?

The collected data were quantified and inputted as nominal or ordinal data into the Statistical Package for Social Science (SPSS, Version 11.5) and the results are presented in graphs, pie charts 
and table. Non-parametric tests of statistical significance (the chi-square test and the Kruskalwallis test) were also used to determine the relationships amongst the gender empowerment variables. The Kruskal-Wallis test was used to analyze multiple independent ordinal variables while differences between nominal variables were tested using chi-square test. Excel spreadsheet was used to summarize and analyze the data collected through focus group discussions, participatory rural appraisal and interviews.

\section{RESULTS AND DISCUSSION}

\subsection{Socio-economic Characteristics of the Respondents}

Fifty percent of the respondents were males and the other $50 \%$ were females. In terms of age composition, $74.8 \%$ were between $31-50$ years old followed by those who were 51 years old and above $(18.8 \%)$ and those who were between 18 30 years old $(6.4 \%)$. Fifty percent of the respondents were married; the widowed $(42.8 \%)$; divorcees $(6.4 \%)$; and singles $(0.8 \%)$. The same proportion of male household heads and female household heads were involved in the survey. The majority of respondents were from Oromo ethnic group (95.2\%) while the remaining came from Amahara ethnic group (4.8\%). The majority of the respondents were Orthodox Christians (87.2\%) followed by $12.4 \%$ Protestant Christians and $0.4 \%$ indigenous Oromo Religion"Wakefata" believers.

About $44.4 \%$ of the respondents had nonformal education followed by primary education $(44 \%)$ and secondary education (12\%). Fifty percent of the respondents have an annual income of between 1,001-5,000 Ethiopian Birr (76-384 Euros), followed by those earning between 5,00110,000 Ethiopian Birr (385-769 Euros) (28\%); those who earn below 1,000 Ethiopian Birr (76 euros) (16.8\%); and those earning greater than 10,000 Ethiopian Birr (769 Euros) $(5.2 \%)$. About $70 \%$ of the farming households earn their income from farming activities while $30.4 \%$ of the respondents earn their income from both farming and nonfarming activities (See Annex 2).

\subsection{Access to Major Productive Resources}

As illustrated in Figures 3 and Figures 4, the results of the data analysis show limited access by female farmers to key productive resources and agricultural services. Females in both maleheaded households and female-headed house-

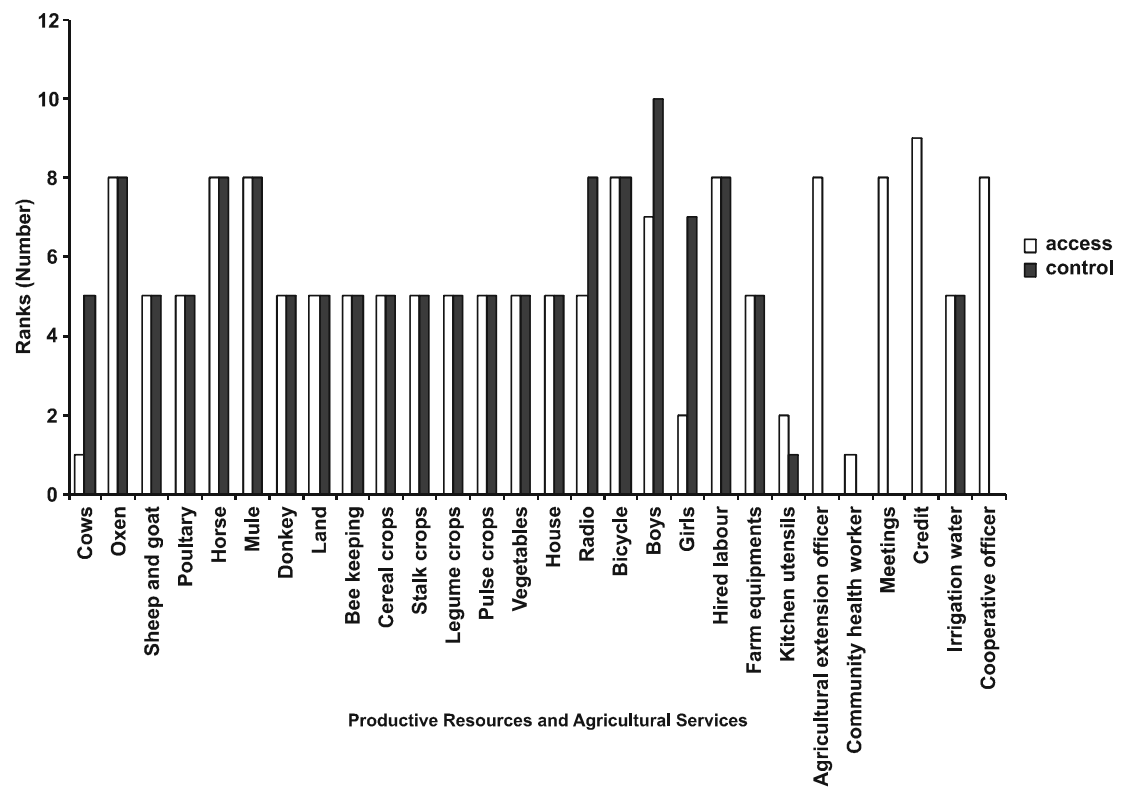

Fig. 3. Females' access and control over resources according to their perception in the three surveyed communities [Source: Field data 2007]. 
holds tend to have poor access to productive resources because of gender division of labour and cultural barriers. The male farmers enjoy better access to productive resources mainly because family headship and gender division of labour.

5.2.1 Access to Farming Land: A greater proportion of the respondents $(55.6 \%)$ acquired farming land through land redistribution; followed by inheritance $(23.6 \%)$; and gifts from relatives $(20.8 \%)$. A greater proportion of the male respondents $(67.2 \%)$ acquired farming land through land redistribution as against $44.0 \%$ by the female respondents. In addition, $27.2 \%$ of the male respondents acquired farming land through inheritance compared to $20.0 \%$ by the female respondents. On the other hand, $36.0 \%$ of female respondents acquired farming land as a gift from relatives as against $5.6 \%$ by the male respondents (Table 1). A chi-square test $\left(\chi^{2}=35.192, \mathrm{df}=2\right.$, $\mathrm{P}<0.05)$ indicates a significant difference between the situation of male and female respondents. To enhance agricultural productivity and address household food security challenges, the findings of this paper clearly indicate the need to increase females' access to farming land.
Table 1: Methods of acquiring farming land by gender

\begin{tabular}{|c|c|c|c|c|c|c|}
\hline \multirow[t]{3}{*}{ Gender } & \multicolumn{6}{|c|}{ Means of acquiring farming land } \\
\hline & \multicolumn{2}{|c|}{$\begin{array}{c}\text { Land } \\
\text { redistribution }\end{array}$} & \multicolumn{2}{|c|}{ Inheritance } & \multicolumn{2}{|c|}{$\begin{array}{l}\text { Gift from } \\
\text { relatives }\end{array}$} \\
\hline & Count & $\%$ & Count & $\%$ & Count & $\%$ \\
\hline Female & 55 & 44.0 & 25 & 20.0 & 45 & 36.0 \\
\hline Male & 84 & 67.2 & 34 & 27.2 & 7 & 5.6 \\
\hline Total & 139 & 55.6 & 59 & 23.6 & 52 & 20.8 \\
\hline
\end{tabular}

Source: Field data 2007.

Twenty-six percent of the respondents have a farm size of less than 0.5 hectares. About $45 \%$ of the female respondents have a farm size of less than 0.5 hectares compared to $7.2 \%$ by the male respondents. On the other hand, $9.2 \%$ of the respondents indicated their farm size is greater than 5 hectares. Out of this category, $16.0 \%$ were males while $2.4 \%$ were females (Fig. 5). There was a significant difference between the situation of male and female respondents (Kruskal-Wallis: $\mathrm{H}=49.348$, $\mathrm{df}=1, \mathrm{p}<0.05)$. Clearly, shortage of land is more severe for female farmers than their male counterparts.

5.2.2 Access to Irrigation Water: Access to irrigation water is one of the important factors in agricultural production. Sixty-four percent

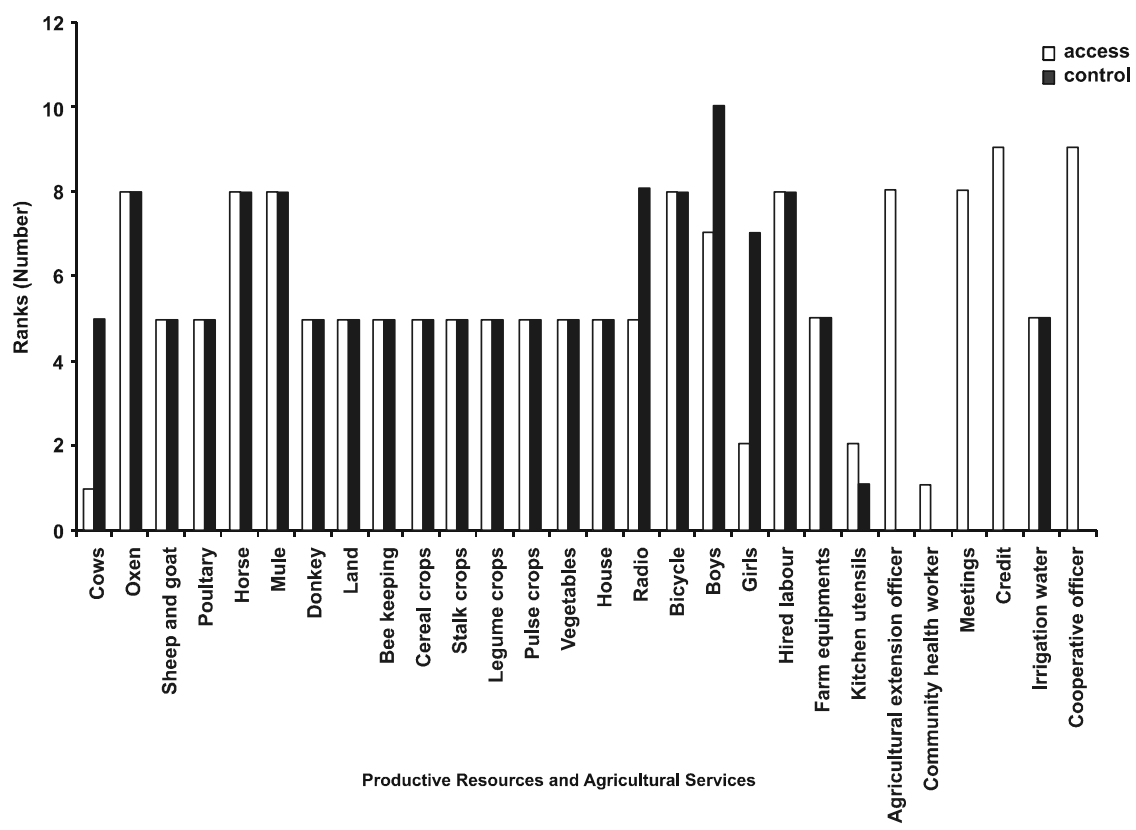

Fig. 4. Males' access and control over resources according to their perception in the three surveyed communities [Source: Field data 2007]. 


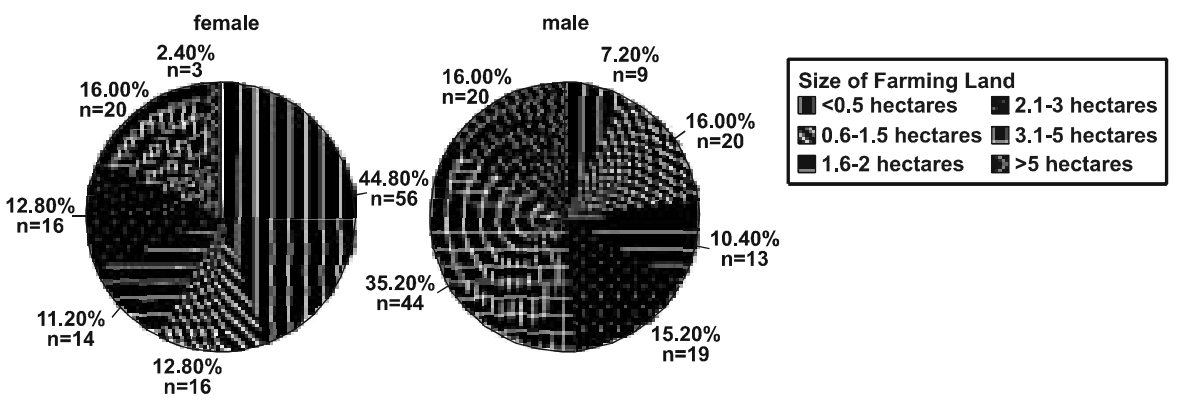

Fig. 5. Size of farming land in the three communities [Source: Field data 2007].

$(64.0 \%)$ of the respondents indicated their dependence on rainfall for their farming activities. About $70 \%$ of female farmers depend on rainfall compared to $58.4 \%$ by their male counterparts. On the other hand, $41.6 \%$ of the male farmers depend on both rainfall and irrigation water as compared to $30.8 \%$ by their female counterparts (Table 2). A chi-square test $\left(\chi^{2}=3.403, \mathrm{df}=1, \mathrm{p}>0.05\right)$ indicates that there is no significant difference between the males and females access to irrigation water. To increase their productivity and address household food security challenges in the surveyed communities, it is important to improve farmers' access to irrigation water.

Table 2: Access of respondents to irrigation water by gender

\begin{tabular}{lccccc}
\hline Gender & \multicolumn{3}{c}{ Access to irrigation water } \\
\cline { 2 - 3 } & \multicolumn{2}{c}{ No } & & \multicolumn{2}{c}{ Yes } \\
\cline { 2 - 3 } \cline { 5 - 6 } & Count & $\%$ & & Count & $\%$ \\
\hline Female & 87 & 69.6 & & 38 & 30.4 \\
Male & 73 & 58.4 & & 52 & 41.6 \\
\hline Total & 160 & 64.0 & & 90 & 36.0 \\
\hline
\end{tabular}

Source: Field Data 2007.

\subsection{Farmers'Access to Major Agricultural Services}

Access to agricultural extension services, credit and rural institutions were identified as the three major services required by small-scale farmers in the three surveyed communities.

\subsubsection{Access to Agricultural Extension} Services: About 54\% of the respondents had access to agricultural extension services, while $45.6 \%$ did not. The proportion of male farmers who enjoyed agricultural extension services was $72.0 \%$ compared to only $36.8 \%$ for female counterparts (Table 3). A chi-square test
Table 3: Access to agricultural extension services

\begin{tabular}{lccccc}
\hline Gender & \multicolumn{2}{c}{ Access to agricultural extension services } \\
\cline { 2 - 3 } & \multicolumn{2}{c}{ No } & & \multicolumn{2}{c}{ Yes } \\
\cline { 2 - 3 } \cline { 5 - 6 } & Count & $\%$ & & Count & $\%$ \\
\hline Female & 79 & 63.2 & & 46 & 36.8 \\
Male & 35 & 28.0 & & 90 & 72.0 \\
\hline Total & 114 & 45.6 & & 136 & 54.4 \\
\hline Sonnnnyyy
\end{tabular}

Source: Field Data 2007.

$\left(\chi^{2}=31.218, \mathrm{df}=1, \mathrm{p}<0.05\right)$ indicates a significant difference between males' and females'access to agricultural extension services. It is vital to design and implement gender responsive extension programme to address the needs of both male and female farmers.

With regard to factors motivating participation in agricultural extension package programme (AEPPs), $78.9 \%$ of the male respondents said they were motivated by development agents to participate in the programme to increase their productivity in comparison to $73.9 \%$ by the female farmers (Fig.6). While development agents clearly play a significant role in motivating rural farmers to participate in AEPPs, a chi-square test $\left(\chi^{2}=\right.$ 5.794, $\mathrm{df}=4, \mathrm{p}>0.05)$ indicates no significant difference between males and females in this regard. Increasing the number and competence of development agents and the introduction of effective agricultural and rural development interventions will significantly help to address the needs of both male and female farmers in Ethiopia.

Development agents $(80.9 \%)$ are the main sources of information on the AEPPs; followed by neighbouring farmers (15.4\%); mass media (2.9\%); and demonstration plots (2.2\%). Eightyseven percent of the female farmers receive information from development agents compared 


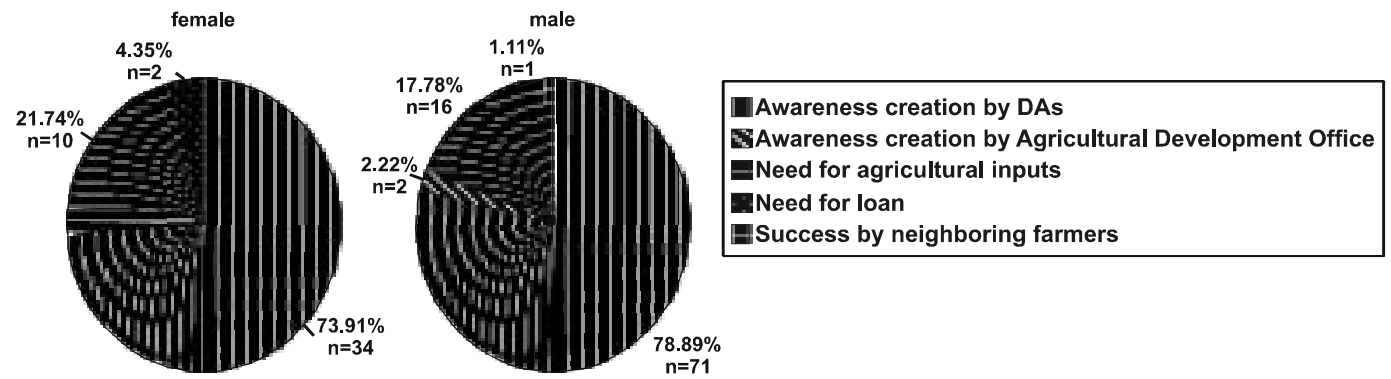

Fig. 6: Factors accounting for farmers' participation in extension package programmes by gender [Source: Field data 2007].

to $77.8 \%$ of their male counterparts (Table 4 ). There was no significant difference between males and females as regards the sources of information on extension programmes $\left(\chi^{2}=5.259, \mathrm{df}=3, \mathrm{p}>0.05\right)$. To promote sustainable agricultural production in rural communities in Ethiopia, it is important to introduce gender responsive capacity building programmes for development agents to enable them to effectively deliver extension services to rural farmers.

Increase in crop production attributable to the AEPPs was confirmed by $66.2 \%$ of the farmers. Production of crops in the three communities increased between half and two-fold. All the male farmers ascribed the two-fold increase in crop production to the AEPPs while all the females indicated that half of the increase in crop production was due to AEPPs (Table 5). A chisquare test $\left(\chi^{2}=136.000, \mathrm{df}=1, \mathrm{p}<0.05\right)$ indicates a significant difference in level of increase in crop production between male and female farmers ascribed to the AEPPs.

5.3.2 Access to Credit Facilities: With regard to access by rural farmers to credit services from various organizations in the three communities, government agencies (GAs) scored the highest $(55.6 \%)$; followed by micro-finance institutions (MFIs) (28.4\%); non-governmental organizations
Table 5: Level of increase in crop production by gender

\begin{tabular}{|c|c|c|c|c|}
\hline \multirow[t]{3}{*}{ Gender } & \multicolumn{4}{|c|}{ Level of increase in crop production } \\
\hline & \multicolumn{2}{|c|}{ Increased by $1 / 2$} & \multicolumn{2}{|c|}{ Increased by two-fold } \\
\hline & Count & $\%$ & Count & $\%$ \\
\hline Female & 46 & 100 & - & - \\
\hline Male & - & - & 90 & 100 \\
\hline Total & 46 & 33.8 & 90 & 66.2 \\
\hline
\end{tabular}

Source: Field Data 2007.

$(8.0 \%)$; neighbouring farmers (NFs) $(4.8 \%)$; and both government agencies and micro finance institutions $(0.8 \%)$. About $6 \%$ of the farmers indicated that they are not interested in credit. About $62 \%$ of female farmers said they resort to government agencies as a source of credit compared to $48.8 \%$ by the male farmers. On the other hand, $31.2 \%$ of the male farmers source credit from micro-finance institutions compared to $25.6 \%$ by their female counterparts (Fig.7). There was no significant difference between male and female farmers as regards the sources of credit for agricultural production $\left(\chi^{2}=12.303, \mathrm{df}=5, \mathrm{p}>0.05\right)$. Improving farmers' access to credit facilities will help to increase their productivity and address household food security challenges.

5.3.3 Access to Rural Institutions: With regard to access to rural institutions, $75.2 \%$ of

Table 4: Farmers' sources of information for extension programmes by gender

\begin{tabular}{|c|c|c|c|c|c|c|c|c|}
\hline \multirow[t]{3}{*}{ Gender } & \multicolumn{8}{|c|}{ Source of information for extension package programmes } \\
\hline & \multicolumn{2}{|c|}{ Development Agents } & \multicolumn{2}{|c|}{ Neighbouring farmers } & \multicolumn{2}{|c|}{ Demonstration Plots } & \multicolumn{2}{|c|}{ Mass Media } \\
\hline & Count & $\%$ & Count & $\%$ & Count & $\%$ & Count & $\%$ \\
\hline Female & 40 & 87.0 & 5 & 10.9 & 1 & 2.2 & - & - \\
\hline Male & 70 & 77.8 & 16 & 17.8 & - & - & 4 & 4.4 \\
\hline Total & 110 & 80.9 & 21 & 15.4 & 1 & - & 4 & 2.9 \\
\hline
\end{tabular}

Source: Field Data 2007. 


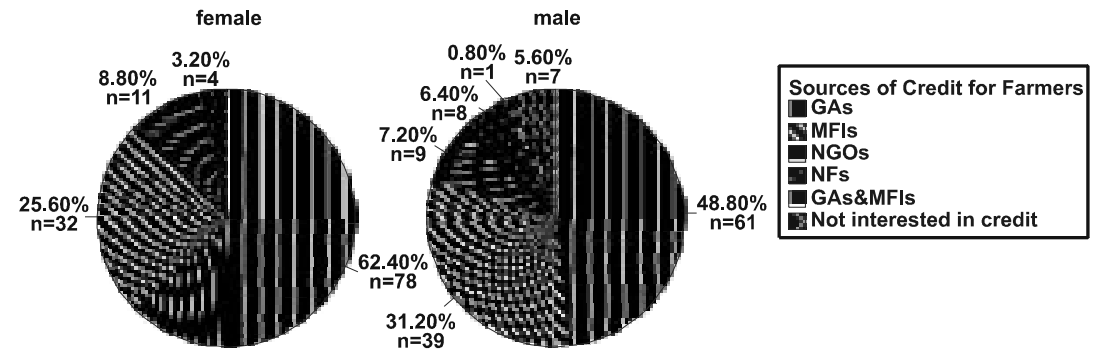

Fig. 7. Sources of credit for small-scale farmers by gender [Source: Field data 2007].

the farmers indicated they are members of peasant associations (PAs) while $20 \%$ are members of both PAs and micro-finance institutions (MFIs). Four percent (4\%) of the farmers belong to both peasant associations and grain bank associations (GBAs) and $0.8 \%$ are members of micro-finance institutions. About $87 \%$ of the female respondents are members of peasant associations compared to $63.2 \%$ of the male farmers. Only $0.8 \%$ of both the male and the female farmers are members of microfinance institutions (Fig. 8). There is a significant difference between male and female farmers' access to rural institutions $\left(\chi^{2}=20.867, \mathrm{df}=3\right.$, $\mathrm{p}<0.05)$. There is therefore, a need to strengthen the existing rural institutions to assist rural female farmers to be increase their productivity.

\subsection{ASWOTAnalysis of Ethiopian Gender Policy}

A SWOT analysis conducted on the gender policy of Ethiopia identified a number of strengths, weaknesses, opportunities, and threats relating to gender empowerment (Table 6). The results of the SWOT analysis should be taken into account in designing effective strategies for promoting gender empowerment, sustainable agriculture and food security in Ethiopia.

\section{DISCUSSION}

The results of the research revealed that female farmers in the three surveyed communities in Ambo District have limited access to agricultural productive assets such as land, irrigation water, extension services, credit and rural institutions in comparison to their male counterparts. This finding supports the observation by the Ethiopian Ministry of Women Affairs (2006) and the International Institute of Rural Reconstruction-Ethiopia (2000) that women's access to resources is constrained by historical and cultural factors, women's lower visibility in the cash economy, and by their limited participation in decision-making (Fernando 1998).

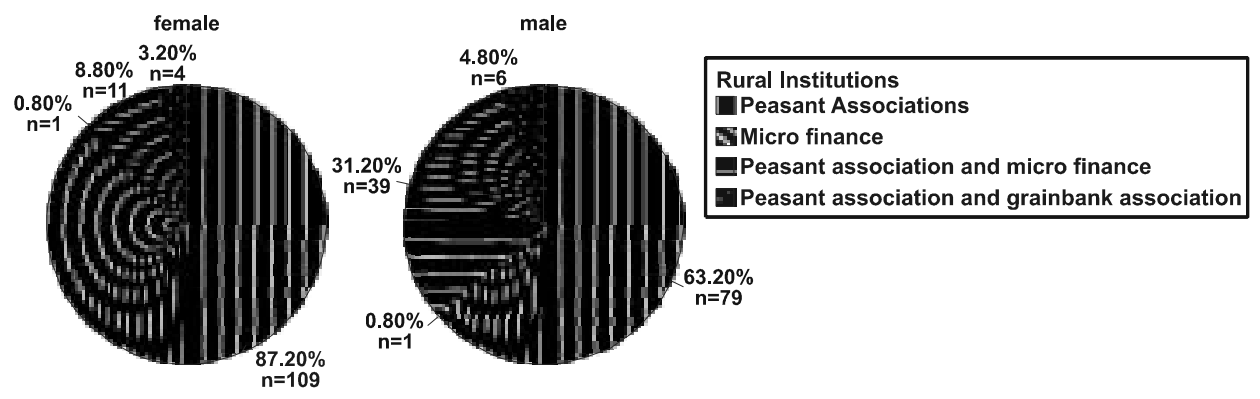

Fig. 8. Access of respondents to rural institutions by gender [Source: Field Data 2007]. 
Table 6: A SWOT analysis for Ethiopian gender policy

Strengths:
- Strong commitment for gender empowerment and
sustainable development;
- Governance: establishment of Ministry of Women
Affairs;
- Gender mainstreaming in activities of line ministries;
- Ratification of international conventions on women
rights;
- Strong constitution for gender equality;
- Presence of democratic, committed and supportive
- Organizational sustainability: presence of Ministry
of Women Affairs;
- Affirmative actions to increase girls' enrollment at
all education levels;
- Strong criminal laws for cases of violation against
women and girls.
women and girls.

Opportunities:

- Political: presence of National Women Policy, presence of Women Affairs Office at regional and sector levels, presence of different women associations, commitment of the government to reform the civil service by mainstreaming gender at all levels, commitment of international organizations in addressing gender issues and presence of a national policy on HIV/AIDS;

- Economic: existence of gender sensitive poverty reduction strategy;

- Social: high demand for qualified female and male gender experts, media coverage on gender, presence of social support systems (indigenous cooperative societies);

- Globalization: technological advancement like internet and telecommunication services;

- Stakeholders/Collaborators: existence of different organizations working on gender and reproductive health issues, availability of donor organizations favouring research activities on gender issues;

- Geographic: natural beauty; Cultural: rich and diverse culture of more than 100 ethnic groups.

Source: Desk Review 2007.

\subsection{Shortage of Productive Resources}

Female farmers in the three communities are constrained by severe land shortage. Although the Ethiopian government has tried to address this problem through constitutional reform in 1995, a lot still needs to be done in order to alleviate gender related land issues in the country (JICA 1999). Access to irrigation water is also very
Weaknesses:

- Human resources: absence of committed and assertive female academicians and researchers;

- Financial resources: absence of gender budgeting and lack of adequate financial support for gender and development;

- Gender-neutral agriculture and rural development policy;

- Crisis driven and donor driven development policy;

- Ministry of Gender is different from Ministry of Women's Affairs;

- No sex disaggregated data in national statistics;

- No mechanism for monitoring and evaluating the implementation of gender strategic plan;

- Lack of awareness, misconception, and fatigue about gender issues among communities and employees at all levels;

- Few income generating schemes for women;

- Lack of effective linkage and interaction amongst policy and development stakeholders; Weak environmental protection policy enforcement and open investment policy for transnational companies.

Threats:

- Location disadvantage;

- Poverty and feminization of poverty ;

- Unstable policy;

- Insignificant number of women in Parliament and Ministries;

- Unemployment and unstable labour market for graduates;

- An alarming population growth rate;

- Presence of harmful traditional practices, customs, discriminatory attitudes, customary laws ...;

- Spread of HIV/AIDS at an alarming rate;

- Lack of qualified human resources in using available technologies;

- Inadequate information exchange system with different stakeholders.

- Globalization: economic insecurity, social and personal insecurity, political instability, cultural dilution, market failure, policy failure and environmental degradation.

- Environmental: drought and floods are common phenomena in Ethiopia;

- The pursuit of economic growth; The poor basically rely on the natural capital to meet their basic needs.

limited in the three communities. The problem is more significant for female farmers mainly because they are largely responsible for ensuring household food security. Providing women with access to productive resources, particularly land, water, financial services and capacity-building, will significantly help to boost food security and livelihoods in rural areas (Wahaj and Hartl 2007). 


\subsection{Weak Agricultural Services}

The dominant approach to research and extension still follows the pattern of "transfer-oftechnology", which is based on the assumption that knowledge is created by scientists to be packaged and spread by extension agents for adoption by farmers. This approach is reported to deny and often suppress local initiatives (World Bank 2006). Extension services for women farmers should be mainstreamed into an integrated extension services package accessible to all farmers. A special initiative that involves women in the delivery of extension services is needed. Without gender mainstreaming, there is a danger that women's agricultural programmes will be marginalized and the bureaucracy responsible for women's programmes becomes entrenched (Saito and Spurling 1992).

Despite Ethiopian government's efforts to help farming communities through the provision of extension services, agriculture is still beset by serious weaknesses, including its gender-neutrality. An effective extension package should consist of various elements including technical information, improved technology and agricultural practices, a reliable and timely supply of production inputs, and credit (Abesha et al. 2000). Since 1994/95, Ethiopia adopted Participatory Demonstration and Training Extension System (PADETES) as the national agricultural extension system (Abesha et al. 2000). However, Compared to male farmers, female farmers in the three communities are not benefiting much from the current agricultural extension package because of its gender-neutrality and the top-down nature of the programme (Gebremedhin et al. 2006).

An important criticism of the PADETES is that it is predominantly supply-driven. In other words, technology packages are prepared based on available on-the-self technologies that are merely transferred to farmers without any adaptation. This approach has been a common feature of all agricultural extension service programmes in the country to date. It is therefore, important that agricultural extension services are demand-driven and based on community resources (Gebremedhin et al. 2006; Abesha et al. 2000).

\section{STRATEGIES FOR ACHIEVING GENDER EMPOWERMENT}

The analysis above shows that the linkages and interactions amongst stakeholders in agriculture and rural development in the three surveyed communities are rather weak. Empowering Ethiopian rural women in agriculture is a multifaceted task and must therefore include several elements such as access to land, credit, extension services, training in agriculture and natural resources management, introduction of low cost technologies and practices that ease women's burden of work and non-agricultural income generating activities (Dejene 2003). According to Olumakaiye and Ajayi (2006), in Sub-Saharan Africa, women have less access to education, labour, fertilizers and other inputs than men. However, when women are provided the same level of education, experience and farm inputs that the average male farmer currently receives, they are able to increase their yield by $22 \%$. It is therefore important that the gender division of labour and cultural barriers faced by female farmers should be addressed through non-formal and formal education. It is also necessary to accord rural institutions greater importance because they are in a good position to significantly help rural farmers to mitigate the socio-economic and environmental challenges they are encountering.

\section{CONCLUSION}

Gender equality and empowerment are at the centre of sustainable agricultural development efforts in Ethiopia and most African countries. The two concepts are key to realizing the poverty reduction strategies of African countries and the achievement of the Millennium Development Goals (MDGs). The elaboration of a national action plan for gender equality in Ethiopia is a good start towards gender empowerment in the country. Gender-neutral development interventions do not have the same impact on rural male and female farmers. Female farmers in the three surveyed communities have limited access to major productive resources such as irrigation water, credit, extension services and rural institutions.

However, facilitating access to productive resources by poor rural female farmers is not a one-time event, but an institutional process requiring permanent adaptation to changing circumstances of power, economics, and culture. An effective implementation of Ethiopia's gender empowerment policy will significantly help to improve the conditions of rural female farmers in the years to come. Without the participation of 
the rural poor female farmers in agricultural development policy formulation and implementation and the establishment of efficient rural organizations to act as countervailing forces to vested interests, it is unlikely that significant progress will be made in increasing access by poor farmers to productive resources and agricul-tural services in Ethiopia.

\section{ACKNOWLEDGEMENTS}

We are very grateful to the Flemish Interuniversity Council (VLIR) of Belgium for providing financial support for conducting this research. We are also very thankful to all the organizations and individuals who have directly or indirectly contributed to the successful accomplishment of the research.

\section{REFERENCES}

Abesha D, Waktola A, Aune JB 2000. Agricultural Extension in the Drylands of Ethiopia. Report No. 9. Oslo, Norway: Drylands Coordination Group.

Africa Partnership Forum (APF) and New Partnership for Africa's Development (NEPAD) 2007. Gender and Economic Empowerment in Africa: 8th Meeting of the African Partnership Forum. Berlin: Africa Partnership forum.

Ambo District Finance and Economic Development Office (ADFEDO) 2007. Socio- Economic Profile 2006/2007 (Unpublished). Ambo, Ethiopia: ADFEDO.

Baden S, Oxaal Z 1997. Gender and Empowerment: Definitions, Approaches and Implications for Policy. BRIDGE (development - gender), Report No.40. Brighton, UK: Institute of Development Studies.

Baden S, Reeves H 2000. Gender and Development: Concepts and Definitions. BRIDGE (development gender), Report No. 55. Brighton, UK: Institute of Development Studies.

Bhatta G 2001. Of Geese and Gander: Mainstreaming Gender in the Context of Sustainable Human Development. Journal of Gender Studies, 10 (1): 17-32.

CIDA 1997. Guide to Gender-Sensitive Indicators. Hull, Quebec: Minister of Public Works and Government Services Canada.

Cherinet H, Mulugeta E 2003. A Profile on Gender Relations: Towards Gender Equality in Ethiopia. Stockholm: Swedish International Development Cooperation Agency (SIDA).

Dejene A 2003. Integrated Natural Resources Management to Enhance Food Security: The Case for Community-Based Approaches in Ethiopia. Working Paper No.16. Rome: Food and Agriculture Organization of the United Nations.

Deressa A, Kelemework F 2005. An Overview of Participatory Research Experience in Ethiopian Agricultural Research System. In: F Reda, H Dadi, M Hassana, A Bekele, (Eds.). Farmer Research Group
(FRG): Concept and Practices. Proceedings of A Workshop. 20-21 October, 2004. Melkassa, Ethiopia: EARO, OARI and JICA.

Deressa TT 2007. Measuring the Economic Impact of Climate Change on Ethiopian Agriculture: Ricardian Approach. Policy Research Working Paper 4342. Washington D.C: The World Bank.

Elson D 1998. Integrating Gender Issues into National Budgetary Policies and Procedures: Some Policy Options. Journal of International Development, 10: 929-941.

FAO 1997. Gender and Participation in Agricultural Development Planning: Lessons from Ethiopia. From <http: //www.fao.org/GENDER/Static/CaseSt/ Eti/eti-e-01.htm\#P225_6160> (Retrieved January $15,2008)$.

Fernando P 1998. Gender and Rural Transport. Gender, Technology and Development, 2: 63-80.

Gebremedhin B, Hoekstra D, Tegegne A 2006. Commercialization of Ethiopian Agriculture: Extension Service from Input Supplier to Knowledge Broker and Facilitator. IPMS (Improving Productivity and Market Success) of Ethiopian Farmers Project. Working Paper 1. Nirobi, Kenya: ILRI (International Livestock Research Institute).

Hunduma T 2006. Local Crop Genetic Resource Utilization and Management in Gindeberet, west central Ethiopia. Master Thesis (Unpublished). Norway: NORAGRIC, Center for Environment and Development Studies.

International Fund for Agricultural Development (IFAD) 2007. Empowerment of the Poor: The Replacement of a System of Peoples' Participation in Publicinitiated Development by One of Public Participation in People-initiated Development. From <http: // www.ifad.org/events/past/hunger/empower.html> (Retrieved April 20, 2008).

International Institute of Rural Reconstruction (IIRR)Ethiopia 2000. Integrating Gender in Development Projects: A Manual for Field Practitioners. Addis Ababa, Ethiopia: IIRR.

Japan International Cooperation Agency (JICA) 1999. Country WID Profile (Ethiopia). Tokyo: JICA Planning Department.

Kabeer N 2003. Gender Mainstreaming in Poverty Eradication and the Millennium Development Goals: A Handbook for Policy Makers and Other Stakeholders. Ottawa: International Development Research Centre.

Ministry of Women's Affairs (MOWA) 2006. National Action Plan for Gender Equality (NAP-GE) 20062010. Addis Ababa: Ministry of Women's Affairs (MOWA).

Odame HH, Hafkin N, Wesseler G, Boto I 2002. Gender and Agriculture in the Information Society. International Service for National Agricultural Research Briefing Paper No.55. The Hague, The Netherlands: ISNAR

Olumakaiye MF, Ajayi AO 2006. Women's Empowerment for Household Food Security: The Place of Education. Journal of Human Ecology, 19 (1): 51-55.

Peter G 2006. Gender Roles and Relationships: Implications for Water Management. Physics and Chemistry of the Earth, 31: 723-730.

Rahman S 2000. Women's Employment in Bangladesh 
Agriculture: Composition, Determinants and Scope. Journal of Rural Studies, 16: 497-507.

Ruzvidzo T 2007. Gender Net, Issue 4. Addis Ababa: Economic Commission for Africa. From<http: // www.uneca.org/eca_programmes/acgd/Publications/ GenderNet07_1.pdf>( Retrieved December 9, 2007)

Saito KA, Spurling D 1992. Developing Agricultural Extension for Women Farmers. World Bank Discussion Paper 156. Washington D.C: World Bank.

United Nations 2002. Johannesburg Summit 2002: Ethiopia-country Profile. From <http: //www.un.org/ esa/agenda21/natlinfo/wssd/ethiopia.pdf > (Retrieved December 4, 2007).

United Nations 2003. United Nations Inter-Agency Network on Women and Gender Equality: Woman Watch (2003). From <http: //www.un.org/women watch/daw/country/national/ethiopia.htm> (Retrieved November 11, 2006)

United Nations Children's Fund (UNICEF) 2006. The State of The World's Children 2007: Women and Children-The Double Dividend of Gender Equality. New York: United Nations Children's Fund (UNICEF).
Wahaj R, Hartl M 2007. Securing Water for Improved Rural Livelihoods: The Multiple-uses System Approach. Rome, Italy: International Fund for Agricultural Development.

Welch CJ, Alemu B, Msaki T, Sengendo M, Kigutha H, Wolff A 2000. Improving Household Food Security: Institutions, Gender, and Integrated Approaches. U.S.A: BASIS Management Entity.

West Shoa Zone Bureau of Finance and Economic Development (WSZBFED) 2007. Socio-Economic Profile for West Shoa Zone 2006/2007 (Unpublished). Ambo, Ethiopia: WSZBFED.

World Bank 2001. Engendering Development through Gender Equality in Rights, Resources and Voice. World Bank Policy Research Report 21776. Washington, D.C. and London: World Bank and Oxford University Press.

World Bank 2006. Promoting Local Innovation: Enhancing IK Dynamics and Links with Scientific Knowledge. IK Note No.76. From < http: // siteresources.worldbank.org/EXTINDKNOW LEDGE/Resources/iknt76.htm> (Retrieved April 2, 2007). 


\section{Annexes I}

Characteristics of the sample in three study communities (Awaro Kora, Gosu Kora and Senkele)

\begin{tabular}{|c|c|c|c|c|c|c|c|c|c|}
\hline \multirow[t]{3}{*}{ Category } & \multirow[t]{3}{*}{ Variables } & \multirow{2}{*}{\multicolumn{2}{|c|}{ Total }} & \multicolumn{6}{|c|}{ Communities } \\
\hline & & & & \multicolumn{2}{|c|}{ Awaro Kora } & \multicolumn{2}{|c|}{ Gosu Kora } & \multicolumn{2}{|c|}{ Senkele } \\
\hline & & No & $\%$ & $\mathrm{No}$ & $\%$ & No & $\%$ & $\mathrm{No}$ & $\%$ \\
\hline \multirow[t]{2}{*}{ Gender } & Male & 125 & 50.0 & 30 & 50.0 & 58 & 50.4 & 37 & 49.3 \\
\hline & Female & 125 & 50.0 & 30 & 50.0 & 57 & 49.6 & 38 & 50.7 \\
\hline \multirow[t]{3}{*}{ Age } & $18-30$ & 16 & 6.4 & 4 & 6.7 & 12 & 10.4 & - & - \\
\hline & $31-50$ & 187 & 74.8 & 32 & 53.4 & 90 & 78.2 & 65 & 86.7 \\
\hline & 51 and above & 47 & 18.8 & 24 & 40.0 & 13 & 11.3 & 10 & 13.4 \\
\hline \multirow[t]{4}{*}{ Marital Status } & Single & 2 & 0.8 & - & - & 2 & 1.7 & - & - \\
\hline & Married & $12 \overline{5}$ & 50.0 & 30 & 50.0 & 58 & 50.4 & 37 & 49.3 \\
\hline & Divorces & 16 & 6.4 & 2 & 3.3 & 14 & 12.1 & - & - \\
\hline & Widowed & 107 & 42.8 & 28 & 46.7 & 41 & 35.6 & 38 & 50.7 \\
\hline \multirow[t]{2}{*}{ Household Title } & $\begin{array}{l}\text { Male Headed } \\
\text { Household }\end{array}$ & 125 & 50.0 & 30 & 50.0 & 58 & 50.4 & 37 & 49.3 \\
\hline & $\begin{array}{l}\text { Female Headed } \\
\text { Household }\end{array}$ & 125 & 50.0 & 30 & 50.0 & 57 & 49.6 & 38 & 50.7 \\
\hline \multirow[t]{2}{*}{ Ethnicity } & Oromo & 238 & 95.2 & 56 & 93.3 & 108 & 93.9 & 74 & 98.6 \\
\hline & Amahara & 12 & 4.8 & 4 & 6.7 & 7 & 6.1 & 1 & 1.3 \\
\hline \multirow[t]{2}{*}{ Source of Income } & Farming Activities & 174 & 69.6 & 41 & 68.3 & 76 & 66.1 & 57 & 76.0 \\
\hline & Farming and & 76 & 30.4 & 19 & 31.7 & 39 & 33.9 & 18 & 24.0 \\
\hline \multirow[t]{3}{*}{ Religion } & $\begin{array}{l}\text { Non-farming activiti } \\
\text { Orthodox } \\
\text { Christianity }\end{array}$ & 218 & 87.2 & 60 & 24.0 & 85 & 73.9 & 73 & 97.3 \\
\hline & $\begin{array}{l}\text { Protestant } \\
\text { Christianity }\end{array}$ & 31 & 12.4 & - & - & 29 & 25.2 & 2 & 2.7 \\
\hline & $\begin{array}{l}\text { Indigenous Oromo } \\
\text { Religion (Wakefata) }\end{array}$ & 1 & 0.4 & - & - & 1 & 0.9 & - & - \\
\hline \multirow[t]{3}{*}{ Education Level } & Non-formal & 111 & 44.4 & 39 & 65.0 & 27 & 23.5 & 45 & 60.0 \\
\hline & Primary & 110 & 44.0 & 20 & 33.4 & 63 & 54.7 & 27 & 45.0 \\
\hline & Secondary & 29 & 11.6 & 1 & 1.7 & 25 & 21.7 & 3 & 5.0 \\
\hline \multirow[t]{4}{*}{ Annual Income } & Less than 1000 Birr & 42 & 16.8 & 9 & 15.0 & 14 & 12.1 & 19 & 25.4 \\
\hline & 1001-5000 Birr & 125 & 50.0 & 34 & 56.6 & 55 & 47.8 & 36 & 48.0 \\
\hline & 5001-10000 Birr & 70 & 28.0 & 17 & 28.4 & 40 & 34.7 & 13 & 17.4 \\
\hline & $\begin{array}{l}\text { Greater than } \\
10000 \text { Birr }\end{array}$ & 13 & 5.2 & - & -- & 6 & 5.2 & 7 & 9.3 \\
\hline
\end{tabular}

Note: 1 euro= 13 Ethiopian Birr.

Source: Field data 2007. 


\section{Annexes II}

Access and control profile of male and female farmers in three study communities (Awaro Kora, Senkele Farisi and Gosu Kora)

\begin{tabular}{|c|c|c|c|c|c|c|c|c|}
\hline \multirow[t]{3}{*}{ Resources } & \multicolumn{4}{|c|}{ According to females } & \multicolumn{4}{|c|}{ According to Males } \\
\hline & \multicolumn{2}{|c|}{ Access } & \multicolumn{2}{|c|}{ Control } & \multicolumn{2}{|c|}{ Access } & \multicolumn{2}{|c|}{ Control } \\
\hline & Females & Males & Females & Males & Females & Males & Females & Males \\
\hline \multicolumn{9}{|l|}{ Livestock } \\
\hline Cows & 8 & 2 & 5 & 5 & 9 & 1 & 5 & 5 \\
\hline Ox en & 3 & 7 & 2 & 8 & 2 & 8 & 2 & 8 \\
\hline Sheep and goat & 5 & 5 & 5 & 5 & 5 & 5 & 5 & 5 \\
\hline Poultry & 9 & 1 & 5 & 5 & 5 & 5 & 5 & 5 \\
\hline Horse & 2 & 8 & 2 & 8 & 2 & 8 & 2 & 8 \\
\hline Mule & 2 & 8 & 2 & 8 & 2 & 8 & 2 & 8 \\
\hline Donkey & 5 & 5 & 5 & 5 & 5 & 5 & 5 & 5 \\
\hline Bee keeping & 5 & 5 & 5 & 5 & 5 & 5 & 5 & 5 \\
\hline \multicolumn{9}{|l|}{ Crops } \\
\hline Cereal Crops & 5 & 5 & 5 & 5 & 5 & 5 & 5 & 5 \\
\hline Stalk crops & 5 & 5 & 5 & 5 & 5 & 5 & 5 & 5 \\
\hline Legume crops & 5 & 5 & 5 & 5 & 5 & 5 & 5 & 5 \\
\hline Pulse crops & 5 & 5 & 5 & 5 & 5 & 5 & 5 & 5 \\
\hline Vegetable crops & 5 & 5 & 5 & 5 & 5 & 5 & 5 & 5 \\
\hline \multicolumn{9}{|l|}{ Other Resources } \\
\hline Land & 5 & 5 & 5 & 5 & 5 & 5 & 5 & 5 \\
\hline House & 5 & 5 & 5 & 5 & 5 & 5 & 5 & 5 \\
\hline Radio & 4 & 6 & 2 & 8 & 5 & 5 & 2 & 8 \\
\hline Bicycle & 2 & 8 & 2 & 8 & 2 & 8 & 2 & 8 \\
\hline Children-boys & 4 & 6 & 2 & 8 & 3 & 7 & 0 & 10 \\
\hline Children-girls & 7 & 3 & 3 & 7 & 8 & 2 & 3 & 7 \\
\hline Hired labour & 2 & 8 & 2 & 8 & 2 & 8 & 2 & 8 \\
\hline Farm equipments & 5 & 5 & 5 & 5 & 5 & 5 & 5 & 5 \\
\hline Kitchen utensils & 8 & 2 & 9 & 1 & 8 & 2 & 9 & 1 \\
\hline Agricultural extension office & cer 1 & 9 & Other & other & 2 & 8 & Other & Other \\
\hline Community health worker & 8 & 2 & Other & Other & 9 & 1 & Other & Other \\
\hline Meeting & 2 & 8 & Other & Other & 2 & 8 & Other & other \\
\hline Credit & 1 & 9 & Other & other & 1 & 9 & Other & Other \\
\hline Irrigation water & 5 & 5 & 5 & 5 & 5 & 5 & 5 & 5 \\
\hline Cooperative officer & 1 & 9 & Other & other & 2 & 8 & other & other \\
\hline
\end{tabular}

The scoring technique: working separately females' and males' group first identified all the resources available at household level. Then 10 points were allocated between females and males according to their perceived relative access to each resource (i.e the right to use it) and a further 10 points were allocated for perceived control of each resource (i.e ownership and decisions on its use). A score of 10 indicates person enjoys total access or control while a score of 5 indicates access or control is shared equally between females and males. 'Other' means that the item is controlled by an entity outside the household.

Source: Field data, 2007. 